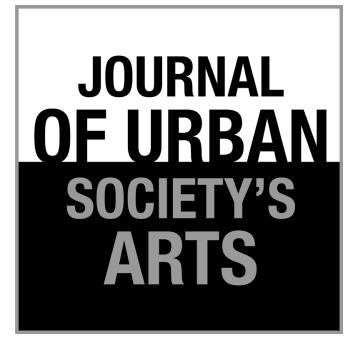

Volume 1 Nomor 1 , April 2014: 57-73

\section{Dialektita Estetika Seni Rupa Kontemporer Bali Melalui Karya Upadana dan Valasara}

\author{
I Gede Arya Sucitra
}

Jurusan Seni Murni, Fakultas Seni Rupa, Institut Seni Indonesia Yogyakarta Jln. Parangtritis Km 6,5 Bantul, Yogyakarta 55001

Tlp. 08175411885 , E-mail: boykbali@gmail.com

\begin{abstract}
ABSTRAK
Penelitian ini membahas estetika karya seni yang tergelar dalam pameran seni rupa Sensuous Objects melalui pendekatan kritik seni rupa. Dua perupa asal Bali yang dikaji merupakan perupa yang berkembang pada era seni rupa kontemporer melalui penciptaan karya melalui spirit lokalitas Bali dengan pendekatan postmodern. Karya yang dihasilkan transmedia dan dengan cita rasa lokal-global. Pendekatan kritik seni melalui empat tahapan analisisnya serta tiga pertimbangan penilaian yang akan menempatkan materi tulisan ini untuk berbincang, berdialog dengan karya seni serta senimannya, sehingga akan ditemukan terjadinya proses transformasi estetis meliputi tema, gaya, fungsi, makna, hingga konsep berkeseniannya. Kritik seni rupa modern pada dasarnya adalah perbincangan mengenai seni (rupa), "art criticism talks about art". Tujuan dari kritik seni adalah pemahaman (understanding), supaya orang memperoleh informasi dan pemahaman yang berkaitan dengan mutu suatu karya seni. Dengan demikian, melalui kritik seni ini pembacaan terhadap karya dua perupa Bali ini akan menemukan muaranya pada pemaparan karakter karya dan konsepsi seni yang dihasilkannya. Penulis mengklasifikasikan karya seni perupa Sensuous Objects ke dalam tiga struktur media penciptaan, yakni media dua dimensional, tiga dimensional, dan seni instalasi. Berbicara tentang karya seni akan tidak utuh jika tidak menyinggung ihwal yang menyangkut medium karena hanya lewat medium itulah, karya seni itu akan memperoleh wujudnya yang konkretlahiriah.
\end{abstract}

Kata Kunci: posmodern, seni rupa kontemporer, kritik seni rupa

\section{ABSTRACT}

\section{Aesthetic Dialectics of Balinese Contemporary Arts through Upadana and}

Valasara's Artworks. This article examines the aesthetic reading of artworks in an art exhibition called "Sensuous Objects" using an art criticism approach. Two artists from Bali are examined as growing artists in the era of contemporary art through the creation of works in the spirit of locality with a postmodern approach in Bali. The resulting work is the trans-media and the local-global flavor. An approach to art criticism through the four stages of analysis and assessment of three considerations will put this writing material in the context of conversation, dialogue with the artwork and the artist, so there is an aesthetic transformation process including the theme, style, function, meaning, and the concept of art. Critics of modern art basically talk about art (visual), "art criticism talks about art". The purpose of art criticism is to understand that people acquire information and understanding pertinent to the quality of artwork. Thus, through the reading of artworks, two Balinese artists find out the exposure to the character and conception of artworks produced. The author classifies the artwork of artists called Sensuous Objects into three structures of media creation such as the two-dimensional media, three-dimensional media, and installation art. Speaking of the artwork will not 
be complete if it does not mention particulars related to the media because only through that medium, works of art will acquire its concrete-outward form.

Keywords: still, squirming, close-up photography, and plant

\section{Pendahuluan}

Lanskap perkembangan seni rupa Indonesia memberikan pengaruh yang besar akan perubahan dan dinamisasi visual karya seni pada wajah seni rupa Bali terutama seni rupa kontemporer Bali. Keanekaragaman budaya seni rupa Bali tidak dapat dilepaskan dari dinamika sejarah Bali masa lalu dan perjalanan seni rupanya. Dalam perkembangannya, sebuah kebudayaan mendapat pengaruh-pengaruh dari luar dirinya dan beradaptasi berkembang seiring perubahan. Kebudayaan Bali yang berkembang saat ini adalah hasil akulturasi budaya lokal dan budaya yang datang dari luar. Hal ini tentunya terjadi juga pada perupa asal Bali yang melanjutkan studi pendidikan seni ke Yogyakarta, sebagai salah satu tempat kawah candradimuka seni rupa Indonesia. Akibatnya, perupa Bali yang sarat akan pengetahuan seni tradisi Bali yang kuat dan budaya yang homogen, harus beradaptasi dengan budaya Yogyakarta yang plural dan kekayaan seni budaya terutama seni rupanya. Mereka tidak jarang mengalami shock of the new, dan tentunya ini kelak memengaruhi pola pikir berbudaya dan pola kreatif penciptaannya.

Kenyataan perubahan kebudayaan yang terjadi dewasa ini membuktikan kebudayaan selalu mengalami transformasi dari masa ke masa (Soedarsono, 1999:160). Hal yang menarik untuk dikaji dalam penelitian ini adalah terjadinya perubahan bentuk visual (transformasi) dan muatan kontekstualnya pada karya perupa Bali di Yogyakarta. Terutama timbulnya kecenderungan karya seni rupa kontemporer Bali yang dikembangkan oleh perupa muda asal Bali yang berproses kreatif dan berkarya seni di Yogyakarta. Perupa yang menjadi fokus penelitian adalah mereka yang menempuh pendidikan seni dan memulai alur proses kreatifnya pada awal tahun 2000-an. Dalam kesehariannya mereka bersentuhan, bergesekan, dan saling 'bersitegang' dengan heterogenitas budaya setempat dan estetika yang terus berkembang. Sudah barang tentu citra-citra karya seni yang mereka produksi mengalami perubahan dari asal tradisinya.

Perkembangan perubahan pola estetik dan fenomena transformasi estetik seni rupa Bali semenjak masa prakolonial, kolonial, modern hingga berlanjut pada era seni rupa kontemporer, melahirkan bahasa rupa dengan berbagai piranti teks dan konteksnya menjadi acuan utama. Representasi yang menampilkan perihal identitas budaya Bali tersebut menurut Hasan (2001: 300) sempat mendominasi dan memberi stigma bahwa seni rupa Bali selalu terkungkung dalam koridor identitas, yakni tradisional. Namun, anggapan ini dikritisi dengan keras oleh Sanento Yuliman, "Jangan semata-mata karena Bali, lantas suatu praktik seni lukis serta merta diberi stampel "tradisional".

Perkembangan seni rupa kontemporer Bali dalam pengamatan Parta (2010: 20), seorang penulis seni rupa Bali, bahwa akhir tahun 1990an hingga awal 2000-an banyak perupa muda Bali mulai mengkritisi diri dan sedapat mungkin berusaha melakukan eksplorasi estetik yang tidak lagi menampilkan representasi identitas budaya, melalui idiom-idiom budaya Bali.

Penelitian ini menekankan pada pembacaan estetika terhadap karya-karya perupa Bali terutamanya terfokus pada studi karya Wayan Upadana dan Made Wiguna Valasara sehingga terbaca perihal bagaimana transformasi estetik seni rupa Bali berkembang di Yogyakarta baik perihal konsep maupun presentasi visual yang telah membentuk wajah seni rupa kontemporer Bali terkini. Pilihan dua perupa ini sebagai pembacaan estetika seni rupa kontemporer Bali setelah mengamati bahwa 
karya-karya mereka memang kini menjadi semacam rujukan yang kuat untuk melihat kecenderungan pola dan medium penggarapan yang dilakukan perupa muda Bali generasi setelah mereka. Penelitian dengan format studi kasus akan melakukan pembacaan estetika perupa Wayan Upadana dan Made Wiguna Valasara yang juga tergabung sebagai anggota organisasi seni Sanggar Dewata Indonesia angkatan 2001 dalam pameran seni rupa yang telah mereka adakan di Bentara Budaya Yogyakarta pada 2-9 Juni 2010 dengan tema Sensous Objects.

Kekaryaan kedua perupa muda dalam pameran Sensous Objects nampaknya memberikan nuansa yang berbeda bagi perkembangan seni rupa Bali sebelumnya, yang riuh bertabur unsurunsur rupa yang digali dari khazanah seni budaya Bali. Untuk beberapa waktu kehadiran karya-karya Upadana dan Valasara tampak clear, formal, dan sekaligus juga menampilkan sensibilitas material dalam mengetengahkan nilai estetik (Parta, 2010: 21). Karya-karya mereka menampilkan pengolahan visual yang lebih terfokus pada eksplorasi estetik, namun juga terkandung nilai kritik budaya. Perkembangan seni rupa kontemporer memberi keleluasaan ruang dalam berbagai eksplorasi intermedium dan tema, gaya, dan eksplorasi lainnya. Sebagai seniman muda, Upadana dan Valasara menunjukkan sebuah eksplorasi medium yang berupaya menghadirkan kebaruan dalam tataran seni rupa kontemporer Bali, tidak hanya untuk disaksikan secara visual, namun juga tersisip nilainilai kontekstual sosiobudaya.

Kehadiran karya seni Upadana dan Valasara tentunya akan melahirkan bentuk dan gaya tertentu sesuai dengan jiwa zaman dan situasi lingkungan yang berkembang. Setiap generasi penerus akan dapat mengenali ciri-ciri yang membedakan antara generasinya dengan generasi sebelumnya. Dengan pembacaan estetika karya seni rupa Bali yang berkembang di Yogyakarta dengan masa yang lebih baru/terkini tentu akan dapat dikenali dan dirunut alur perkembangan dan perubahan baik secara estetik, fungsi, dan maknanya berdasarkan kelenturan dan keluwesan sikap kreatif di dalam ruang dan waktu yang berbeda.

Proses perkembangan kekaryaan dan pengetahuan seni Upadana dan Valasara tidak dapat dilepaskan dari pengaruh lingkungan karena mereka dilahirkan dan juga berkembang saat mereka merantau mengikuti pendidikan seni di Yogyakarta. Faktor-faktor internal dan eksternal sangat berperan besar pada pribadi mereka dalam menanggapi berbagai macam kegelisahan, wacana, ketegangan budaya yang terungkap dalam perilaku serta hasil karya seninya. Untuk itu, penting kiranya diamati faktor-faktor apa saja yang memengaruhi proses kreatif kedua perupa tersebut sehingga kekaryaan yang dihasilkan mengandung karakter yang berbeda dengan karya seni budaya (Bali) tempat mereka dilahirkan. Bahasan berikutnya dilanjutkan dengan pemaparan pendekatan estetika pada karya Upadana dan Valasara sehingga dapat dikenali karakter personal kekaryaan, proses kreatif, dan makna yang terkandung dalam karya "Sensous Object”.

\section{Yogyakarta sebagai Medan Kreatif Budaya}

Yogyakarta sebagai lokasi tujuan merantau Upadana dan Valasara tentu bukan sekadar tempat singgah untuk mematangkan pengetahuan seni melalui pendidikan tinggi seni di ISI Yogyakarta. Yogyakarta memiliki sejarah budaya yang hampir sama dengan Bali; kebudayaan rakyat/tradisi masih terpelihara, masih ada keraton yang jika di Bali disandingkan dengan Puri (rumah raja), salah satu tujuan wisata yang diperhitungkan dunia, dan keseniannya dengan berbagai macam genre yang berkembang pesat. Medan kreatif inilah yang menumbuhkan rangsangan kreativitas bagi perupa muda. Aura budaya dan wibawa kota Yogyakarta sebagai kota budaya dan kota pendidikan telah mendorong terjadinya migrasi para calon pekerja seni dan intelektual ke kota Yogyakarta. Kota Yogyakarta lebih cocok sebagai tempat belajar dan berkarya bagi para pekerja seni dan intelektual karena kehidupan di kota ini suasananya tenteram dan nyaman. Yogyakarta adalah kota yang dinamis dalam hal kehidupan seni dan ilmu pengetahuan.

Ditinjau dari perspektif kebudayaan, karya seni hadir dalam hubungan yang kontekstual dengan ruang dan waktu tempat karya bersangkutan dilahirkan. Dengan perspektif ini, kelahiran sebuah karya seni selalu dimotivasi oleh berbagai persoalan 
yang terjadi dalam masyarakat. Seniman sebagai masyarakat tentunya akan selalu bersentuhan langsung dengan berbagai masalah, fenomena yang berkembang di lingkungan sekitarnya. Kemunculan karya seni sebagai sebuah entitas ekspresi personal seniman menurut Saidi (2008: 1) bisa merupakan representasi dan abstraksi dari realitas, tetapi bisa pula 'pendobrakan' atas realitas tersebut. Dengan demikian, seni bukan media langsung dari realitas. Seni bukan sekadar imitasi realitas, melainkan sebuah dunia dengan realitas baru hasil interpretasi seniman atas realitas sebenarnya.

Dalam konteks pembacaan ruang dan waktu serta situasi sosial budaya yang melingkupi penciptaan karya seni para seniman, penting kiranya untuk mengamati lebih lanjut tentang keberadaan seni budaya suatu tempat yang kemudian banyak memengaruhi alur berpikir, proses kreatif, dan sosialisasi personal seniman. Hal ini menjadi penting diamati lebih lanjut karena seniman yang menjadi subjek penelitian adalah seniman yang berasal dari luar Yogyakarta yang datang merantau ke Yogyakarta dengan budaya dan paradigma berpikir sesuai dengan budaya asalnya. Selain itu, seniman yang karyanya menjadi subjek penelitian juga merupakan lulusan perguruan tinggi seni, yakni Institut Seni Indonesia (ISI) Yogyakarta dan di perguruan inilah mereka mengalami pergesekan dengan berbagai macam kecenderungan ideologi, budaya, agama, dan pemahaman berkesenian. Lebih lanjut, Yogyakarta kemudian menjadi rumah kreatif ruang penggodog berkesenian, sekaligus pendidik mentalitas mereka memberikan pertumbuhan proses berkesenian yang pesat dan penuh tantangan. Yogyakarta juga menjadi tempat terjadinya konfrontasi antara tradisi dan pembaharuan. Mengenai peta kekuatan akademis dan modal kultural tersebut, seperti yang diutarakan Burhan (2009:11) dalam tulisan katalog pameran besar seni visual Indonesia 'Exposign' 25 Tahun ISI Yogyakarta:

Di samping aspek-aspek akademis itu, ternyata ada dukungan-dukungan lain yang ternyata sangat potensial. Iklim kota Yogyakarta dengan nuansa kultural yang tidak pernah sepi dengan aktivitas kesenian, kegiatan ilmiah, kegiatan para intelektual, mahasiswa aktivis beserta demo-demonya, serta even-even upacara tradisional memberikan dukungan iklim yang kondusif bagi para calon seniman untuk mengkristalkan pengalaman hidupnya. Untuk itu, karya-karya mereka kebanyakan mengungkapkan semangat hidup yang meluap-luap. Sistem pendidikan Jurusan Seni Murni FSR ISI, sebagai salah satu contoh, yang telah disempurnakan terus menerus itu akhirnya sampai sekarang tetap memberikan karakter lulusan yang berbeda dengan mahasiswa-mahasiswa seni rupa ITB Bandung. Dalam hal yang demikianlah, kontroversi antara mazhab Yogya dan Bandung dalam seni lukis Indonesia, memang didukung juga oleh sistem pendidikan yang berlainan. Perbedaan itu bahkan telah berakar jauh ke belakang pada masa sekitar zaman revolusi sebagaimana dalam catatan Claire Holt, "To the revolutionary and romantic generation of artists assembled in Jogja, Bandung art appeared alien and cold, even meaningless".

Tentu akan menjadi suatu pembedaan yang jelas, hasil persentuhan budaya Yogyakarta yang diperkuat oleh sistem pendidikan seni di ISI Yogyakarata terutama di FSR, ISI Yogyakarta terhadap hasil kreatif mahasiswanya dengan produk lulusan FSRD, ITB Bandung. Tantangan tersebut sebenarnya terus terjawab dengan dijalankannya tradisi pembentukan seniman-seniman yang ditempa dengan ciri yang kuat pada penguasaan skill praktik dan bentuk-bentuk yang berkarakter kuat, serta ketajaman konsepnya. Di samping itu, hampir dapat dipastikan bahwa seniman-seniman FSR, ISI Yogyakarta dapat lahir tentu bukan dari norma kurikulum lembaga pendidikan yang ketat, tetapi oleh ruang kreativitas yang longgar.

Sistem ini sebenarnya merupakan turunan langsung dari tradisi pengajaran di sanggarsanggar besar, dari Sanggar Pelukis Rakyat, Sanggar Bambu, hingga Sanggar Dewata Indonesia yang sangat memberikan kebebasan pada kreativitas para anggotanya. Keberadaan komunitas seni dan sanggar-sanggar seni yang berkembang baik yang 
dibentuk oleh semangat kedaerahan asal perupanya ataupun dibentuk oleh suatu sikap kesenian yang seideologi sangat besar memengaruhi dinamisasi pengetahuan seni dan eksperimental kekaryaan mahasiswa seni/perupa di Yogyakarta. Dari sistem ini, tradisi melukis yang penuh kebebasan dan kreativitas penciptaan sering memunculkan karya-karya mahasiswa dengan kreativitas yang tidak terduga. Dalam usaha untuk melahirkan keunikan personal style, sistem ini dengan sendirinya meletakkan mahasiswa berada dalam iklim kompetisi terus-menerus.

\section{Pembahasan}

Foto tersebut menampilkan batang pohon serut yang dibonsai sehingga meskipun ukurannya mungil, namun karakter tua dan kokoh muncul begitu kuatnya (lihat gambar 6). Kegempalan serat pada batangnya yang berkelok-kelok menimbulkan keyakinan akan kesempurnaannya. Dengan dikomposisikannya batang serut ini secara horizontal, imajinasi yang tervisualkan memperlihatkan bagian mata seekor buaya. Kulit batang pohon serut ini menjadi nampak seperti kulit buaya yang keras dan tebal. Buaya digambarkan sebagai sosok yang cukup berbahaya, dingin dan tenang penampilannya, namun mengisyaratkan akan ancaman bagi mangsanya.

Persoalan awal yang menarik perhatian pada pameran seni rupa Sensuous Objects yang tergelar di Bentara Budaya Yogyakarta pada tahun 2010 adalah ide kreatif dan kecerdasan mengeksplorasi medium. Karya perupa muda ini menghadirkan kecenderungan eksplorasi medium yang berbeda, segar, dan unik terutama dipandang dari karakter estetika seni rupa Bali. Seperti yang diungkapkan Rosidi (2010:8), kurator pameran Sensuous Objects sebagai berikut:

Sensuous Objects diambil sebagai judul untuk menekankan bagaimana I Wayan Upadana dan Made Valasara berangkat dalam menjelajah medan kreatifkekaryaanya dari persoalan eksplorasi medium. Sensuous Objects mengacu pada hubunga antarsemua benda, dan benda-benda itu mengada meskipun tanpa kehadiran persepsi. Dalam pameran ini, judul tersebut sebagai penanda bagaimana kehadiran fisik sebuah objek dan relasi di antara objek-objek itu sendiri menjadi sesuatu yang penting. Walaupun pada akhirnya, karya-karya Valasara dan Upadana beronjak juga untuk mempersoalkan konteks yang lebih luas...

Dua perupa yang menjadi artist pameran seni rupa ini adalah I Wayan Upadana (kelahiran 1983) dan Made Wiguna Valasara (kelahiran 1983) merupakan perupa asal Bali yang mengikuti pendidikan seni di ISI Yogyakarta angkatan 2001. Konteks kreativitas mengolah medium dua dan tiga dimensional dengan berbagai media alternatif yang diperkuat karakter tema dan kebentukan tradisi lokal (Bali) seperti : polyester resin, cat mobil dan kanvas; akrilik, dakron, dan benang di atas kanvas; polyester resin, bathtube, cat mobil dan stainless steel; polyester resin, cat mobil, dan kran air; plastik temuan dan kertas kemasan produk; dan polyester resin, aluminium dan stiker. Hal ini menjadi lebih menarik lagi karena pengaruh berproses kreatif di Yogyakarta ternyata juga memberikan dampak kritis karena perspektif memandang ke-Bali-an pastinya telah mengalami transformasi sosial-budaya selain secara keilmuan seni mereka mengalami gejolak gemblengan penciptaan secara akademis di FSR, ISI Yogyakarta. Interaksi sosial budaya seniman dan lokasi dia berproses kreatif sangat memengaruhi output estetika karyanya. Dalam karya seni rupa, selain media dan teknik termuat pula nilainilai sosial, politik, filsafat pada zamannya yang dikonsep dan dikonstruk oleh senimannya dalam wujud karya seni (Ardi, 2006:199).

\section{Analisis Estetika Karya Perupa Upadana dan Valasara}

Bahasan berikut ini akan langsung melakukan pembacaan atas data diri perupa yang menjadi subjek penelitian; gambaran dunia seninya (interaksi sosial budaya); analisis karya melalui pendekatan estetika Feldman meliputi tema, fungsi, gaya, dan gramatika visual diperkuat kemudian dengan pendekatan kritik seni melalui proses deskripsi, analisis, interpretasi, evaluasi atas karya yang dipilih khususnya yang dipamerkan dalam pameran 
Sensuous Objects. Pada sesi kritik ini akan dapat terlihat pencapaian estetika karya melalui eksplorasi intermedium yang menghasilkan kebentukan karya yang khas dari perupa. Melalui empat tahap kritik seni di atas akan terbongkar persoalan formalistik (teks) serta persoalan konteks yang luas. Untuk itu, pasti akan terjadi penafsiran sehingga makna karya dapat terungkap. Fungsi penafsiran di sini bukan untuk menduplikasi makna atau merekonstruksi setepat-tepatnya sikap mental dari kreator (si senimannya), melainkan juga untuk memproduksi makna melalui penafsiran. Memahami karya seni bukanlah suatu gerak kembali ke kejadian masa lalu, melainkan suatu partisipasi sekarang dan di sini pada apa yang sedang terjadi (Marianto, 2001: 202).

Penting kiranya pembacaan estetika karya dan penelusuran atas hubungan kontekstual antara karya seni dengan ruang dan waktu saat karya tersebut dilahirkan. Dalam hal ini mengakomodasi asimilasi budaya Bali dari senimannya dengan budaya Jawa sebagai ruang berproses kreatif. Hubungan ini menyebabkan konsekuensi logis bahwa pemahaman terhadap kesenian secara otomotis membutuhkan pemahaman pula terhadap ruang dan waktu tersebut (aspek sosial-budaya). Kesenian, sebagaimana dikatakan Yuliman (2001), tidak dapat sepenuhnya dipahami tanpa menempatkannya dalam keseluruhan kerangka masyarakat dan kebudayaan. Hubungan timbal balik inilah yang menyebabkan munculnya pendapat bahwa karya seni yang baik adalah suara zaman.

\section{Pembacaan Estetika Visual Karya Upadana dan Valasara}

Pembacaan karya seni yang tergelar dalam pameran seni rupa Sensuous Objects dilakukan melalui pendekatan kritik seni. Pendekatan kritik seni melalui empat tahapan analisisnya serta tiga pertimbangan penilaian yang telah diuraikan pada landasan teori, akan menempatkan penulis untuk berbincang, berdialog dengan karya seni serta senimannya, sehingga akan ditemukan terjadinya proses transformasi estetis meliputi tema, gaya, fungsi, makna, hingga konsep berkeseniannya. Feldman (1967: 446) menyatakan kritik seni rupa modern pada dasarnya adalah perbincangan mengenai seni (rupa), "art criticism is talk about art". Tujuan dari kritik seni adalah pemahaman (understanding), supaya orang memperoleh informasi dan pemahaman yang berkaitan dengan mutu suatu karya seni (Feldman, 1967: 444).

Karya seni perupa Sensuous Objects penulis klasifikasikan ke dalam tiga struktur media penciptaan, yakni media dua dimensional, tiga dimensional, dan seni instalasi. Berbicara tentang karya seni akan tidak utuh jika tidak menyinggung ihwal yang menyangkut medium karena hanya lewat medium itulah, karya seni itu akan memperoleh wujudnya yang konkret-lahiriah. Sifat-sifat lahiriah inilah yang memungkinkan para pengamat potensialnya menggapai gagasan yang hendak diketengahkan oleh penciptanya. Medium bukan segala-galanya, namun medium itu dapat diberi peran yang cukup menentukan, tentunya pada karya seni yang hanya dilihat sebagai sistem organik atau katakanlah kesatuan estetik (Sahman, 1993: 42).

\section{Karya Dua Dimensional}

Para perupa Upadana dan Valasara berkarya dengan media dua dimensional menggunakan material yang berbeda. Itulah sebabnya, dalam berkarya mereka melakukan eksplorasi intermedium. Medium merupakan segala material yang digunakan untuk mencipta. Bentuk jamak dari medium adalah media (Ragans, 2005: 42). Implimentasinya dalam bidang dua dimensi semisal lukisan, pelukis menggunakan media seperti crayon, cat, pensil, charcoal, dan media pelengkap lainnya dalam satu bidang karya. Karya yang terpamerkan di sini secara prinsipnya dapat dikatakan lukisan. Seperti yang diketengahkan oleh (Sahman, 1993: 55) mengenai lukisan sebagai berikut.

Technically, painting is the art of spreading pigments, or liquid color, on a flat surface (canvas, panel, wall, paper) to produce the sensation or illusion of space, movement, texture, and form, as well as the tensions resulting from combinations of these elements. It is understood, of course, that through these technical devices are expressed the intellectual, emotive, symbolic, religious, and other 
subjective values presented elsewhere in this book. Sometimes it is difficult to mark the line between painting and drawing, because both arts apply colored materials to a surface of a different color; but painting usually involves the use of a brush and of fluid color.

\section{Karya Lukisan I Wayan Upadana}

Secara formalistik, karya ini menampilkan bentuk media ungkap yang tidak lazim terutama pada pemilihan geometri kanvas. Umumnya kanvas berbentuk persegi (kotak), namun lukisan Upadana yang berdimensi diameter $150 \times 80 \mathrm{~cm}$ ini menerapkan kanvas yang melingkar (lihat gambar 1). Model spaan seperti ini bukannya tanpa masalah dalam pemasangan, dibutuhkan kerapian dan kesabaran untuk mendapatkan bentang kanvas yang rata dan tidak berlipat/bergelompang di tepi spaan (kayu perentang). Karya yang dikomposisikan secara panel jejer tiga memberikan bentuk repetisi satu sama lainnya baik mengenai konsep panorama langit maupun leleran yang menjulang ke atas.

Pada teknis penggarapan artistiknya, konsep garis sebagai elemen visual terbentuk dari goresan kuas atau jejeran titik yang membentuk garis. Ragans mengatakan "line is an element of art that is the path of a moving point through space" (Ragans, 2005: 70). Garis yang dihasilkan dari permainan kuas Upadana bukanlah garis nyata yang tampak berdiri tunggal, garisnya dibentuk dan dihasilkan dari tepian bidang objek seperti yang tampak pada tepian lelehan yang bertemu dengan latar langit ataupun garis yang terbentuk hasil persinggungan bidang warna pada awan. Garisnya bukanlah garis tradisional hasil dari goresan seperti tarikan pada kuas atau pena drawing, namun dihasilkan dari komposisi bidang warna dan objek.

Medium alternatif yang digunakan meliputi material polyester resin, cat mobil, dan cat akrilik. Bidang lingkaran kanvas dibagi nyaris secara simetris untuk meletakkan panorama langit dan horizon bidang berwarna cokelat diperkuat dengan leleran berjumlah tiga buah menjulang ke atas. Langit berwarna biru cerah dengan penggarapan realistik, bidang biru mendominasi bagian atas, dan barisan awan putih serta ungu pada sisi bawah merapat garis cakrawala. Elemen bidang cokelat yang terbuat dari cetakan resin yang sebelumnya telah didesain mengikuti alur lingkaran kanvas. Jika langit memiliki tesktur semu, pada elemen cokelat mengandung tekstur nyata sehingga ketika diraba seperti meraba coklat meleleh yang telah mengeras. Bisa dikatakan komposisi elemen visual digarap secara minimalis, tidak riuh dengan elemen dekoratif. Ringan dan mudah untuk dinikmati secara visual.

Upadana disiplin dalam penciptaan patung. Sejak awal pendidikannya dia selalu memadukan dua unsur media penciptaan, yakni seni lukis dan patung. Hal ini dapat ditelusuri karena semula di SMSR dia mengambil minat seni lukis, sehingga tidak ayal dalam berkarya Upadana melakukan terobosan kreatif dengan eksplorasi lintas bidang. Karya ini berdasarkan judul yang diterapkan, yakni Mencair ke Angkasa, menampilkan kegelisahan Upadana tentang keadaan di bumi yang semakin padat dengan bangunan-bangunan bertingkat dan keterbatasan lahan, hutan yang digunduli lalu berakibat pada keseimbangan ekosistem; terjadinya banjir, tanah longsor, dan bencana lainnya. Air yang menjadi bagian penting kehidupan menjadi pertanyaan personal Upadana ketika tanah tidak mampu lagi menyerap air "ke mana lagi air itu akan mengalir?" Lelehan ke atas tersebut merupakan sebuah kekuatan, memiliki daya levitasi, dapat merupakan simbolisasi dari peradaban manusia dengan gedung-gedungnya yang tinggi menjulang menuju angkasa dan dapat juga merupakan kekuatan alam untuk melawan kekuatan dari manusia itu sendiri seperti legenda terbentuknya gunung-gunung yang menjulang tinggi dari permukaan bumi dan menembus langit.

Karya ini cukup menarik dalam pengolahan gagasan dan perangai penampilan karya yang lembut, tenang, dan minimalis. Seperti sebuah visualitas puisi alam yang kerap dituliskan Upadana di kala mencipta. Kesan persepektif berhasil dihadirkan walau secara lembut melalui penempatan objek awan yang makin mengecil ketika mendekati horizon dan meninggi ketika mendekati mata penonton. Tentu perlu disingkapi lebih lanjut oleh Upadana untuk menghadirkan kesan tanah yang menjulang ke atas dengan komposisi leleran yang berbeda baik secara volume maupun ukuran. Kesan 


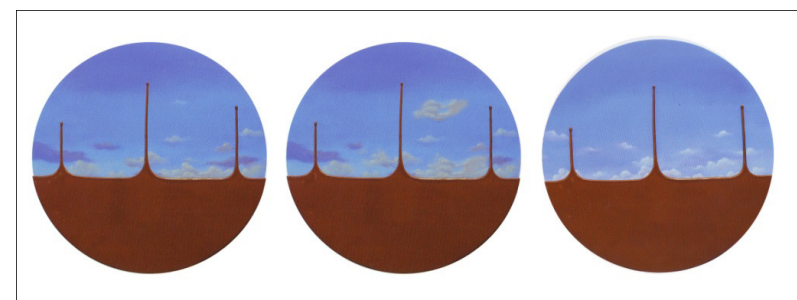

Gambar 1. Mencair ke Angkasa, 2010, Diameter $150 \mathrm{x}$ $8 \mathrm{~cm}$ (3 panel), cat akrilik, polyester resin, cat mobil, dan kanvas (Rep. katalog pameran seni rupa "Sensuous Objects", 2010).

tenang dan menyentuh batin seperti lantunan syair alam mengenai renungan akan alam terekspresikan dengan baik dan tentunya dengan finishing karya yang rapi. Seperti yang diungkapkan Upadana "craftsmanship, skill harus tetap menjadi kekuatan utama untuk karya yang menyentuh batin dan rasa”. Hal ini mengingatkan konsep dasar seni rupa tradisional Bali, yakni olah craftsmanship pada setiap penciptaan karya untuk menghasilkan karya yang maksimal, rumit, halus, dan rasa keindahan yang kuat.

\section{Karya Lukisan Made Wiguna Valasara}

Pengamatan awal melihat lukisan ini, tampak jelas kesan formalistik minimalis dengan media ungkap yang unik dan tidak umum. Sesosok Barong yang merupakan makhluk mitologi yang disakralkan oleh masyarakat Hindu Bali dirupakan dengan warna putih bersih dan dalam tekstur emboss layaknya tekstur bed cover selimut untuk kamar tidur. Bidang kanvas karya berbentuk persegi empat dengan ukuran sama sisi 200 x 200cm (gambar 2).

Teknik yang diterapkan oleh Valasara ialah teknik emboss melalui proses penjahitan kain kanvas yang sebelumnya sudah dipolakan sesuai dengan kebutuhan kebentukan karya. Lalu kain tersebut diserahkan ke tukang jahit untuk menjahit pola desain pada kain kanvas. Selanjutnya kanvas yang sudah terpolakan melalui benang jahitan akan dimasukkan dakron (material empuk seperti kapas, namun sintetis biasanya untuk pengisi bantal) melalui sisi belakang kanvas hingga padat membentuk testur bergelombang.

Kanvas yang sudah terpasang pada kanvas lalu dilumuri cat akrilik putih berkali-kali hingga tebal dan diakhiri dengan mengamplas permukaan cat menjadi halus hingga benang jaritan pembentuk

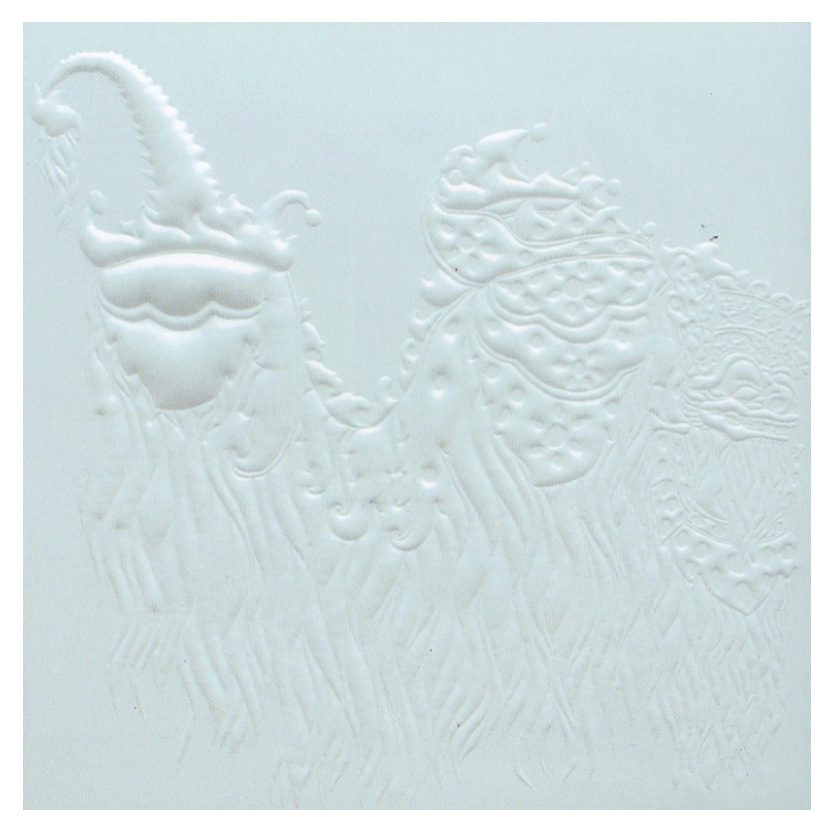

Gambar 2. Kehilangan Taring Maka Tampak Samar (Emboss Series), 2009, 200 x 200cm, Akrilik, dakron, dan benang di atas kanvas (Rep. katalog pameran seni rupa "Sensuous Objects", 2010).

bidang emboss tidak tampak lagi. Warna yang diterapkan pun sangat sederhana hanya warna putih. Kesan garis tampak dari pola jaritan emboss sehingga garis ini dihasilkan dari pertemuan bidang datar dan bidang kembung tidak melalui goresan pena, kuas, ataupun pertemuan bidang warna. Di sinilah garis menemukan definisinya sendiri melalui proses kreatif karya Valasara.

Pengolahan perspektif tidak terlalu penting pada karya berjudul Kehilangan Taring Maka Tampak Samar karena karya tampak flat seperti timbul sedemikian rupa dari balik kanvas. Komposisi bidang terasa penuh walau bidang seutuhnya berwarna putih karena tepian kanvas bawah dan kiri kanan tampak terlalu merapat terhadap objek. Konsep karya dua dimensional Valasara mengusung ketertarikan terhadap flatness objek tiga dimensi ke dalam unsur dua dimensi. Hal ini kemudian memperkuatnya menerapkan teknik emboss sebagai olah kreatif dari gagasan tersebut melalui tematema kontemporer.

Dari penerapan judul terlihat sikap kritis Valasara terhadap kontekstualitas budaya atas fenomena degradasi sikap penghormatan masyarakat Bali terhadap figur sakral yang disucikan. Barong sebagai elemen penanda keluhuran Dharma, kebenaran, dan kebaikan mulai memudar dan hanya sebagai 
pemanis identitas Dharma. Valasara berhadapan dengan situasi budaya pariwisata di daerah tinggalnya Sukawati, di mana Barong dihadirkan hanya sebagai asesoris kapitalis tanpa penghayatan sikap moralitas yang layak. Jika tidak dipahami dan dijaga wibawanya, lambat laun akan semakin susah dikenali antara yang spiritual dan profan. Maka lama-lama kesakralan Barong akan kehilangan taring dan lambat laun samar-samar akan terlupakan.

Teknik emboss dengan warna bidang flat putih berhasil menghadirkan satir, kegelisahan atas kondisi spiritualitas perupa akan fenomena budaya. Kecakapan teknis Valasara berhasil memadukan antara formalisme, ekspresi personal dengan dunia gagasan yang konstektual. Harmonisasi bidang, warna, garis, dan eksplorasi media menjadi begitu kuat menghadirkan karakter kekaryaan Valasara.

\section{Karya Tiga Dimensional}

Kemampuan perupa Bali dalam olah karya tiga dimensi tidak dapat disangsikan lagi. Sekadar mencatat ingatan eksistensi pematung Bali yang eksentrik, yakni I Nyoman Cokot (18881971) kelahiran desa Tegalalang, Gianyar. Gaya primitivisme Cokot rupanya bertolak dari arca-arca tua pura. Kemoderenan Cokot justru terdapat pada primitivismenya. Patung-patung Bali yang dikenal halus dan proporsional, pada Cokot justru menonjol sifat liar tanpa tatanan baku. Dia mengambil tematema agama Hindu yang dikerjakan berdasarkan bentuk dan sifat bahan kayunya. Kayu yang tidak terpakai oleh rata-rata pematung Bali, dia angkat menjadi bahan patung, berdasarkan tuntutan kondisi bahan tersebut. Instingnya bekerja secara naluriah mengikuti wujud bahan kayunya. Batang, dahan, dan ranting, dia biarkan sesuai wujudnya dengan tema mitologi Bali yang 'diminta' oleh si kayu. Ia menerima alam sebagai bentuk jadi patung-patungnya. Cokot tinggal memberikan makna agama padanya. Meskipun bersifat dekoratif Bali, namun berisi ekspresi pribadinya yang purba dan religius. Kayu apa saja yang ditemui Cokot menjadi karya seni. Gayanya yang liar dan primitif, tanpa penghalusan, justru merupakan daya tarik karya-karyanya (Sumardjo, 2009: 59).

Eksistensi Cokot tentunya menjadi inspirasi luas para pematung generasi selanjutnya. Kedua perupa Sensuous Objects menyadari kekuatan dan totalitas seni Cokot. Secara luas di Bali tumbuh beragam pematung yang mendalami gaya cokot yang akhirnya menjadi Cokotisme. Upadana, salah satu generasi pematung yang mengagumi keliaran imajinasi dan idealisme Cokot. Kemampuan Cokot mengolah media temuan alam akhirnya juga secara tidak sadar menginspirasi Upadana dan Valasara untuk merespons karakter materi medium mempresentasikan gagasan.

Seni patung menurut Sahman (1993: 79) dalam Encyclopedia Americana dikatakan sebagai berikut.

Sculpture is the branch of the fine arts that is primary concerned with the creation of expressive forms in three dimensions. It includes a wide range of different kind of art work, extending from freestanding, independent objects, through various forms of high, medium, and low relief, to extreme forms of low relief than are a little more than raised drawing.

Sepadan dengan definisi tersebut, Ragans mengklasifikasikan karya patung dalam dua tipe, yakni sculpture in the round atau dikenal juga freestanding sculpture, yaitu patung yang dapat dilihat dari segala sisi, berbentuk realistik dapat disentuh walau secara kebentukan tidak harus dengan objek yang dikenal. Tipe kedua yakni relief object, objek dengan permukaan datar dan didesain dilihat dari sisi depan atau satu sisi pengamatan (Ragans, 2005: 50). Karya Upadana dan Valasara bergerak dalam dua tipe ini. Silih berganti dalam setiap penciptaan karya mereka memasuki dua tipe ini menyesuaikan karakter material atau motivasi gagasannya.

\section{Karya Patung I Wayan Upadana}

Dalam pameran ini, Upadana menghadirkan dua karya tiga dimensional, yakni berjudul Euphoria Globalisasi bertahun 2010, dengan dimensi objek $170 \times 72 \times 85 \mathrm{~cm}$, dibentuk dengan material polyester resin, bathup, cat mobil, dan stainless stell (gambar 3). Karya berikutnya berjudul Glo-Babi-sasi, bertahun 2010, dimensi bidang 40 x 50 x $60 \mathrm{~cm}$, dengan material polyester resin, cat 


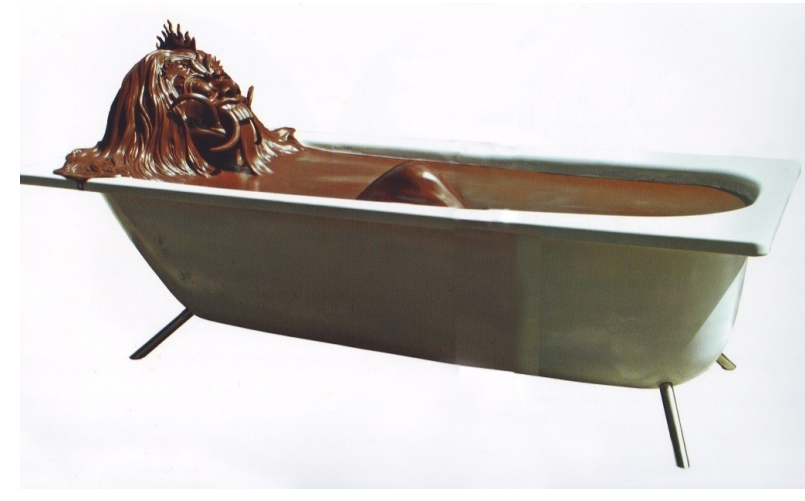

Gambar 3. Euphoria Globalisasi, 2010, $170 \times 72 \times 85 \mathrm{~cm}$, polyester resin, bathtube, cat mobil, dan stainless stell. (Rep. katalog pameran seni rupa "Sensuous Objects", 2010).

mobil, dan kran air (gambar 4).

Karya Euphoria Globalisasi menghadirkan figur Rangda (merupakan makhluk mitologi spiritual Bali) dalam wujud tubuh berwarna cokelat dengan karakter wajah yang seram, mata melotot, gigi yang berukuran besar menyeringai dengan taring selayaknya lengkungan taring babi hutan. Sosok Rangda terlihat sedang bersantai, berendam di bathtube yang airnya berwarna cokelat seperti cokelat cair yang kental. Dengan kaki kanan menekuk dan bagian lutut terlihat menyembul di atas permukaan air.

Objek Rangda terbuat dari polyester resin dan bathtube yang digunakan merupakan material ready made yang $170 \times 72 \times 85 \mathrm{~cm}$, biasa digunakan untuk perlengkapan mandi di kalangan masyarakat modern. Unsur penunjang lainnya pada bathtube adalah ditambahkannya kaki-kaki dari pipa stainless stell sebagai dudukan bathtube. Bathtube dicat berwarna putih. Patung digarap dengan teknik cetak casting (cor/tuang) yang biasanya diterapkan untuk metal (perunggu), namun dalam karya ini menggunakan medium polyester resin dan teknik assembling (karya dirakit menggunakan berbagai bahan yang diambil dari lingkungan sekitar seperti barang industri, bathtube, pipa stainless still yang disatukan menjadi wujud tiga dimensi). Medium produk industri paling banyak dipakai dan digemari para pematung antara lain fibre glass atau resin. Di samping harganya memang murah dibanding material industri lain, dalam pengolahannya serat gelas lebih mudah dan patung dapat diproduksi dengan lebih cepat. Bahkan, terbuka kemungkinan luas untuk dilapisi dengan material lain; kuningan, perak, perunggu, dan seterusnya. Sehingga material aslinya tak tampak lagi, seolah-olah material itu sepenuhnya terbuat dari logam (Hasan, 2006: 12).

Karya patung Upadana ini menghadirkan ikon Rangda, yang dalam mitologi spiritual budaya Bali diyakini sebagai unsur penyeimbang spiritual. Biasanya berdampingan dengan Barong. Rangda dalam posisi sebagai penguasa kegelapan, adharma dan Barong sebagai figur kebenaran, dharma. Rangda dihadirkan dengan bentuk minimalis, gaya yang meminimalkan unsur dekoratif seperti layaknya patung tradisional Bali. Secara volume objek mengikuti ukuran manusia umum karena bathtube yang dipakai adalah bathtube ready made yang terjual bebas di toko bangunan.

Gagasan Upadana memandang modernitas di Bali melalui simbol Rangda sebagai representasi kondisi mental masyarakat Bali sebagai penyangga modernitas dan pariwisata budaya sangat menarik dan kritis. Bali yang kini seakan-akan dicagarkan sebagai kandang pariwisata budaya dibuat terlena dan nyaman dengan berbagai predikat Pulau Bali di mata dunia. Karya ini ingin merepresentasikan keadaan masyarakat Bali saat ini di tengah kepungan budaya global yang sarat dengan isu kenyamanan, masyarakat Bali pun mau tidak mau mesti menikmati keadaan tersebut di tengah usaha mereka untuk mempertahankan nilai-nilai tradisinya.

Kedatangan wisatawan ke Bali tentunya membawa berbagai dampak yang positif maupun negatif. Di tengah kesakralan nilai-nilai adat dan tradisinya, Bali juga menjadi ladang yang sangat subur bagi para pemilik modal yang bergelut dalam pariwisata. Kehidupan masyarakatnya pun menjadi dilematis karena berada di bawah arus tradisi yang kuat dengan tekanan modernisasi dan pengaruh globalisasi yang kuat pula. Akan tetapi, masyarakat Bali juga sangatlah menikmati keadaan tersebut karena mereka membuka diri pada pengaruh asing. Kegelisahan Upadana juga terkait dengan kondisi kepemilikan tanah di Bali akibat kapitalisme pariwisata. Di balik rasa ingin nyamannya, masyarakat Bali bisa saja menjual tanahnya sebagai lahan pariwisata hanya sekadar untuk berfoya-foya, menaikkan derajat social, namun tanpa disadari tradisinya 
kini menjadi budaya tontonan, banyaknya orang datang ke Bali untuk melihat keunikan nilai tradisinya, sebagai sesuatu yang langka pada era yang serba praktis, global dan instan. Kenyataannya kini banyak hal yang dulunya sakral kini hanya bersifat profan tontonan.

Upadana secara teknis formal berhasil menghadirkan karya patung yang mengimajinasikan keadaan yang nyaman dengan karakter karya yang bersih, akurat secara teknis cor, assembling, dan finishing yang rapi. Kecerdasan dalam mengaplikasikan ikon Rangda sebagai pengganti sikap dualitas Rwa Bhineda masyarakat Bali, di sisi lain sangat religius dan di lain hal sangat duniawi. Barangkali akan lebih tampak menyentuh dan fenomenal jika karya patung tidak hanya satu, namun ada beberapa jenis dengan berbagai macam pose Rangda dan tetap satu konsep bentuk dengan bathtube. Dengan demikian, kesan euphoria akan lebih terasa dan massal.

Patung Upadana berikutnya mengambil figur seekor babi yang berendam di wastafel. Dengan tubuh sepenuhnya terendam di bawah air yang seperti karakter cokelat kental dan kepala tetap menyembul di atas genangan air dengan ekspresi wajag tersenyum dan sepucuk bunga kamboja Bali tersemat di telinga kanan. Air cokelat kental tampak akan tumpah meluber hingga tepian wastafel ditandai dengan tiga buah lekukan tetesan pada tepi wastafel. Ukuran karya mengikuti ukuran wastafel ready made yakni $40 \times 50 \times 60 \mathrm{~cm}$, yang tersedia luas di toko bangunan. Karakter objek dibuat dengan teknik yang sama dengan karya Euphoria Globalisasi.

Upadana menghadirkan dua komponen simbol pada karya ini, yakni menampilkan sosok babi yang berendam di dalam lumuran cokelat di dalam wastafel, di mana babi adalah simbol kekayaan, kenyamanan dalam masyarakat tradisional Bali serta mempresentasikan wastafel sebagai citra gaya hidup budaya urban. Kegelisahan Upadana terhadap kondisi psikologis sebagian masyarakat Bali yang saat ini berada dalam kondisi nyamannya di tengah serbuan globalisasi dan urbanisasi di dalam industri pariwisata, "bukankah rasa nyaman itu adalah teror yang membunuh kita" demikian seloroh Upadana.

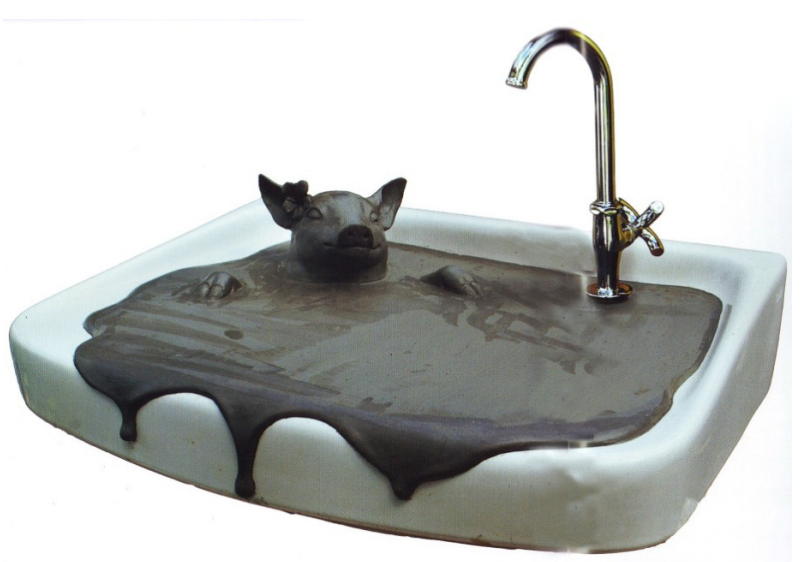

Gambar 4. Glo-Babi-sasi, 2010, $40 \times 50 \times 60 \mathrm{~cm}$, Polyester resin, cat mobil, dan kran air. (Rep. katalog pameran seni rupa "Sensuous Objects", 2010).

Judul Glo-Babi-sasi menghadirkan ktitik yang tepat mengenai kondisi ini. Pemilihan judul pada karya seni memberikan arti yang kuat dan penting dalam proses presentasi karya ke penikmat seni dan menilai makna yang hendak dikomunikasikan senimannya. Upadana tampaknya berhasil dan tepat merangkai objek sesuai pesan dengan judul. Karya dihadirkan dengan karakter yang ringan, manis, dan sangat familiar dalam dunia keseharian masyarakat urban. Pemilihan media intermedium sangat menarik untuk mempresentasikan ide mengenai gaya hidup instan, siap pakai, dan mudah buang dalam perilaku urban.

\section{Karya Patung Made Wiguna Valasara}

Karya patung Valasara hadir dengan ikon Barong Bali melalui interpretasi baru yang unik dan menarik. Mitos Baru, Refleksi Budaya secara formalis mempresentasikan barong dengan bentuk dan ukuran menyerupai aslinya. Ornamentik asesorisnya dibuat dengan abstraksi menyederhanakan gelung ukiran Barong. Material penghias Barong dibuat dengan barang bekas seperti kardus pembungkus barang, tas plastik, dan kabel elektronik. Gestur tubuh barong dalam posisi duduk, seakan menunggu (gambar 5).

Teknik penciptaan yang digunakan adalah assembling, dari merakit berbagai macam barang temuan sehingga menjadi karya tiga dimensi. Gaya yang dihadirkan melalui fantasi terhadap material tubuh Barong. Fantasi dengan tetap berpegang pada 


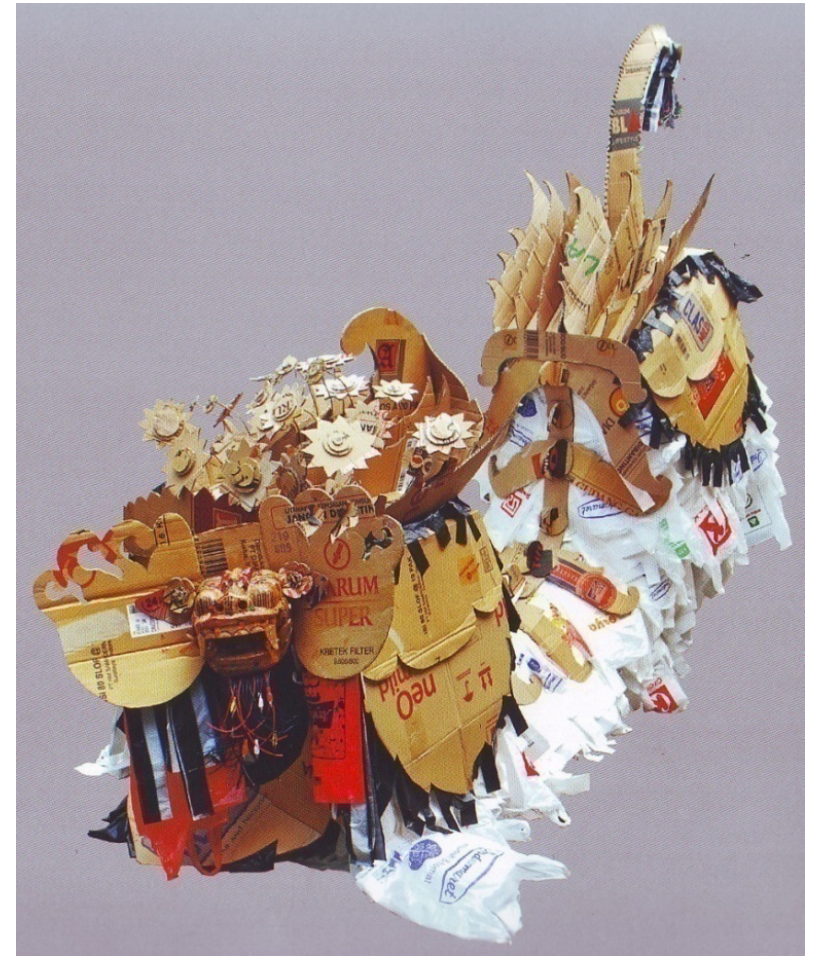

Gambar 5. Mitos Baru, Refleksi Budaya, 2010, variable dimension/ mixed media (plastik temuan dan kertas kemasan produk). (Rep. katalog pameran seni rupa "Sensuous Objects", 2010).

bentuk realistik barong. Umumnya pembuatan barong yang digunakan untuk kebutuhan spiritual religious membutuhkan dewasa ayu, yakni hari baik menurut kalender Bali, material pembentuk yang telah disucikan dan perupanya yang sudah memiliki kesucian hati dan keiklasan dalam berkarya. Materi yang digunakan dari kulit kerbau untuk ukiran, topengnya dari kayu nangka, bulunya dari rambut ekor kuda atau bulu gagak, material logamnya dari emas, kuningan, dan perak serta pelengkap lainnya seperti benang, kaca, kain, bambo, dan lonceng kaki dari logam.

Melalui karya berjudul Mitos Baru, Refleksi Budaya, Valasara merefleksikan kondisi budaya Bali dengan transformasi material pada kedirian barong. Seperti diungkapkan Valasara bahwa figur barong menggunakan kemasan produk, menggambarkan bagaimana pergeseran keyakinan masyarakat menuju budaya konsumerisme, keyakinan pada benda-benda modern sampai pada titik kebutuhan primer, dan juga tanpa disadari limbah produk tersebut berdampak buruk pada lingkungan.

Pemilihan judul menjadi salah satu keberhasilan Valasara atas kontekstualisasi gagasannya

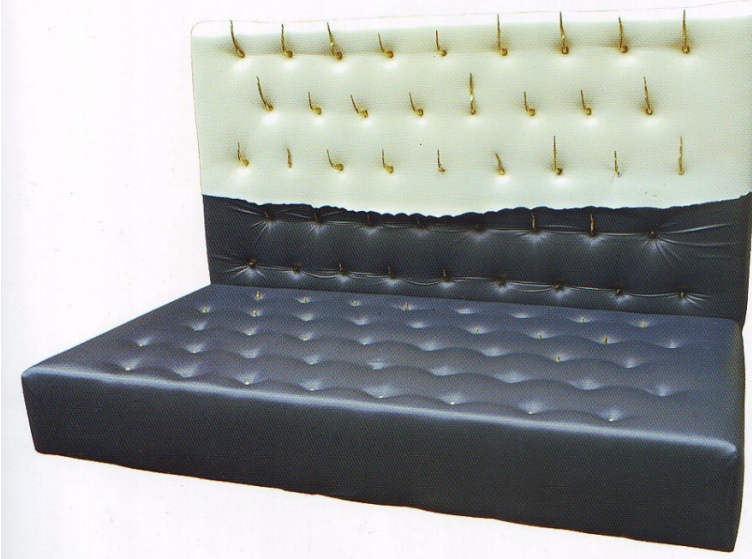

Gambar 6. Tumbuh dari Ego, 2010, $200 \times 100 \times 100 \mathrm{~cm}$, cat krilik, kuningan, spon, dakron, dan kanvas. (Rep. katalog pameran seni rupa "Sensuous Objects", 2010).

dengan intermedium yang digunakan pada Barong. Seniman patung modern sangat sadar memanfaatkan perkembangan revolusioner di bidang bahan. Penemuan dalam industri kimia yang menghasilkan macam-macam medium telah memudahkan pekerjaan para pematung masa kini. Selain makin banyak pilihan, kehadiran medium-medium baru, itu membuat karya-karya menjadi lebih beragam. Karya dibuat dengan presisi artistik dan maket yang berorientasi pada bentuk realistik Barong. Karya yang mampu memberikan penafsiran atas kegelisahan fenomena budaya terkini.

Karya patung Valasara ini berbentuk tempat tidur dengan ukuran $200 \times 100 \times 100 \mathrm{~cm}$, dengan pewarnaan dengan pola horizontal, yakni dua warna; abu-abu hitam dan kuning krem (lihat gambar 6). Pada sisi tepian karya yang digunakan sebagai sandaran cenderung dominan kuning krem dengan hiasan pengait dari bahan kuningan dan pada sisi atas tempat tidur pada beberapa tekstur jahitan terdapat duri seperti tunas muda dari material kuningan.

Warna dikomposisikan untuk memberikan penekanan bawah yang gelap dan atas sebagai unsur penerang dengan warna krem. Warna dari bahan cat akrilik yang dikuaskan dengan merata melalui beberapa lapis lalu di amplas hingga tebal dan halus. Karya di-display seperti halnya meletakkan tempat tidur, yakni menempel pada sisi tembok.

Gagasan karya ini berangkat dari kehidupan hedonis masyarakat urban, khususnya yang telah tersentuh budaya pariwisata. Fasilitas mewah dan 


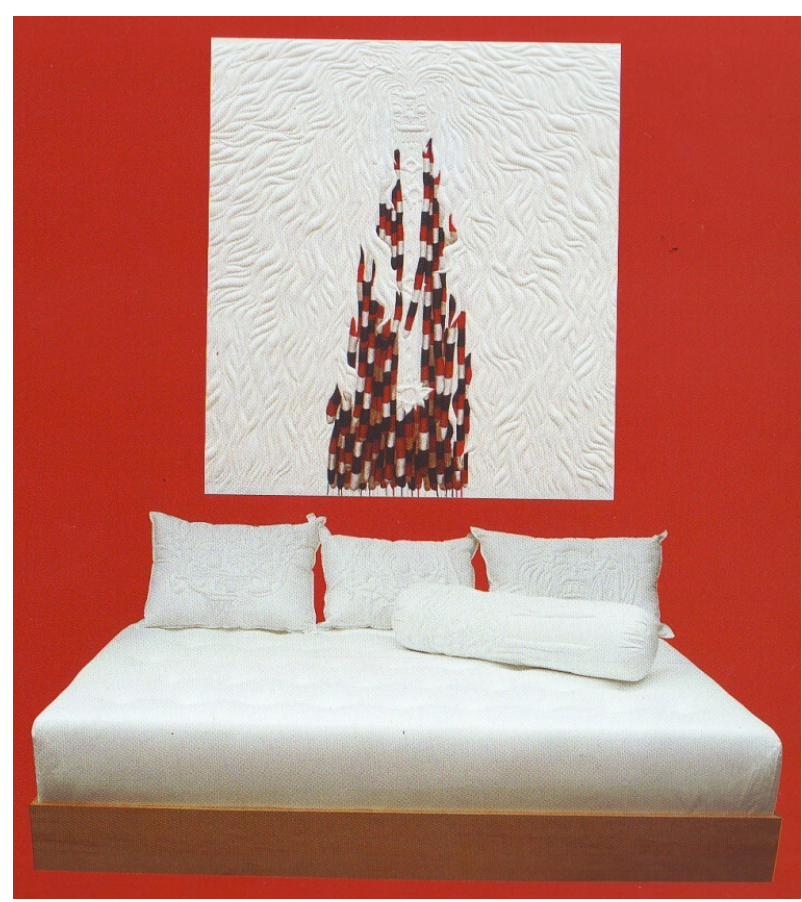

Gambar 7. Tidur dalam Kenangan (Emboss Series), 2009-2010, ariable dimension, cat krilik, spon, dakron, benang, dan kanvas. (Rep. katalog pameran seni rupa "Sensuous Objects", 2010).

kenyamanan hidup menyebabkan tumbuhnya ego individu dan menjauhkan diri dari sikap-sikap toleransi dan norma tradisi. Ego yang tumbuh dari kenyamanan hidup ini nantinya akan menusuk diri sendiri. Kenyataan ini memang sedang melanda dalam dinamika kehidupan masyarakat Bali. Tempat tidur, sebagai simbol ruang privasi yang menandakan kepribadian seseorang, menjadi simbol yang kuat atas interpretasi Valasara atas perubahan sikap dan nilai-nilai budaya di masyarakat tempat tinggalnya. Karya yang sangat kuat mempresentasikan isu transformasi sosial di Bali dengan aplikasi media yang total dan unik.

Karya ini masih sekonsep dengan karya dua dimensional Valasara, yakni Kehilangan Taring Maka Tampak Samar (Emboss Series), serta pengungkapannya dengan teknik emboss. Secara formal karya ini menerapkan tipe patung yang freestanding dan relief sculpture. Freestanding-nya pada kebentukan tempat tidur dan bantalnya, sedangkan relief pada karya dua dimensi dengan teknik embosnya. Pada bentuk formal, relief berfigur Rangda dengan rambut yang menjuntai melebar memenuhi ruang kanvas (lihat gambar 7).

Karakter Rangda juga diterapkan pada kebentuhan tempat tidur dan keempat bantal.
Materi karya menggunakan bahan dari kain kanvas, benang, dakron, spon, dan cat akrilik. Warna terdiri dari unsur dominan putih pada bentuk tempat tidur dan pada relief menerapkan warna hitam, merah, dan putih. Warna merah dan hitam diaplikasikan pada pewarnaan asesoris depan Rangda, sedangkan rambut dan pakaian berwarna putih.

Karyanya masih dalam seri kritik budaya atas pengaruh teknologi dan pariwisata atas sikap dan mentalitas masyarakat penyangganya. Rangda yang biasanya dijunjung karena hadir sebagai antitesis Barong sebagai dualitas yang saling menyeimbangkan. Namun, ketika hanya Rangda saja sebagai acuan mentalitas, orientasinya bukan lagi pada kebenaran, melainkan pada kesenangan yang cenderung menyesatkan.

Karya Valasa menghadirkan sindiran yang halus, yang harus dipahami dengan pengenalan konteks budaya. Inilah muatan yang penting dalam kekaryaan Valasara, karyanya tidak hanya membicarakan keunikan, keindahan, dan keterampilan olah medium, tetapi juga kontekstualitas atas fenomena budaya tempat seniman bertempat tinggal. Situasi inilah yang kemudian menuntun seniman mengeksplorasi gagasan untuk bisa merefleksikan isu-isu kontemporer. Karya yang sangat idealis, karena dengan simbol Rangda dan berbentuk tempat tidur tentu bukan perkara mudah dalam peletakan dan penikmatannya apalagi jika dikoleksi oleh kolektor asal Bali.

\section{Karya Seni Instalasi}

Seni instalasi atau seni mengolah ruang menjadi salah satu metode berkarya yang selalu merangsang perupa untuk mengeksplorasinya. Perupa Upadana dan Valasara pada berbagai kesempatan pameran selalu tertarik untuk mengolah media penciptaan ini dengan dialog keruangan galeri yang tentunya membutuhkan ruang khusus minimal pada sisi luas ruang untuk berdialog dengan penikmat seni. Apa sebenarnya seni instalasi tersebut?

Istilah "installation" (instalasi) muncul sebagai daftar tersendiri pada referensi buku umum bahkan hadir lebih awal daripada yang terdapat di The Art Index. The Oxford Dictionary of Art (1988) 
mendefinisikan istilah instalasi sebagai "term which came into vogue during the 1970s for an assemblage or environment constructed in the gallery specifically for a particular exhibition" (Reiss, 1999: xiii). Dari definisi tersebut, dapat dikatakan instalasi diadakan dan dihadirkan pada konstruksi suatu ruang pameran di galeri. Instalasi seni bisa saja berupa abstrak atau gambar (pictorial), teratur atau spontanitas. Objek-objek terpisah bisa saja termasuk di dalamnya, atau tidak ada objek sama sekali. Selalu ada sebuah hubungan timbal balik beberapa objek antara karya seni dan penikmat, ruang (space) dan karya seni, dan ruang dan penikmat (Reiss, 1999:xiii).

Karya instalasi Upadana dan Valasara merupakan sebentuk karya yang merespons ruang dan berinteraksi dengan penikmat seni melalui apresiasi gagasan dan konsep visual. Adapun dua karya yang akan dibahas adalah Upadana berjudul Cerita Tentang Alamku Kini dan Valasara dengan karya Membakar Ruang.

\section{Karya Instalasi I Wayan Upadana}

Visualisasi karya instalasi Upadana menggunakan material kayu jati yang diperkuat dengan aplikasi logam kuningan untuk membentuk helai daun. Upadana mengeksplor artistik serat kayu yang alami lalu mengolahnya dengan teknik pahat baik secara halus maupun tekstur kasar.

Material kayu dibentuk menyerupai batang kayu namun pada sisi bawah (akar) menyerupai tetesan air. Bagian atas batang kayu dibentuk dengan pahatan bertekstur lalu mengecil ke bagian bawah dan berbentuk meliuk seperti liukan tubuh ular. Bagian ini digarap dengan halus. Unsur batang minimalis tanpa ornamentik. Pada bagian atas batang, terdapat beberapa helai daun dari material kuningan.

Display karya diletakkan tergantung pada sisi tengah ruangan, secara center untuk mendapatkan panorama yang luas dan interaksi dengan penonton. Dengan batang yang berjumlah 50 buah dengan ukuran yang variatif, menjadi begitu padat dan mencuri perhatian penonton. Motivasi gagasan karya Upadana dipicu oleh keadaan alam yang kian kering, gersang, dan rusak (lihat gambar 8).

Karya ini timbul atas kegelisahan tentang

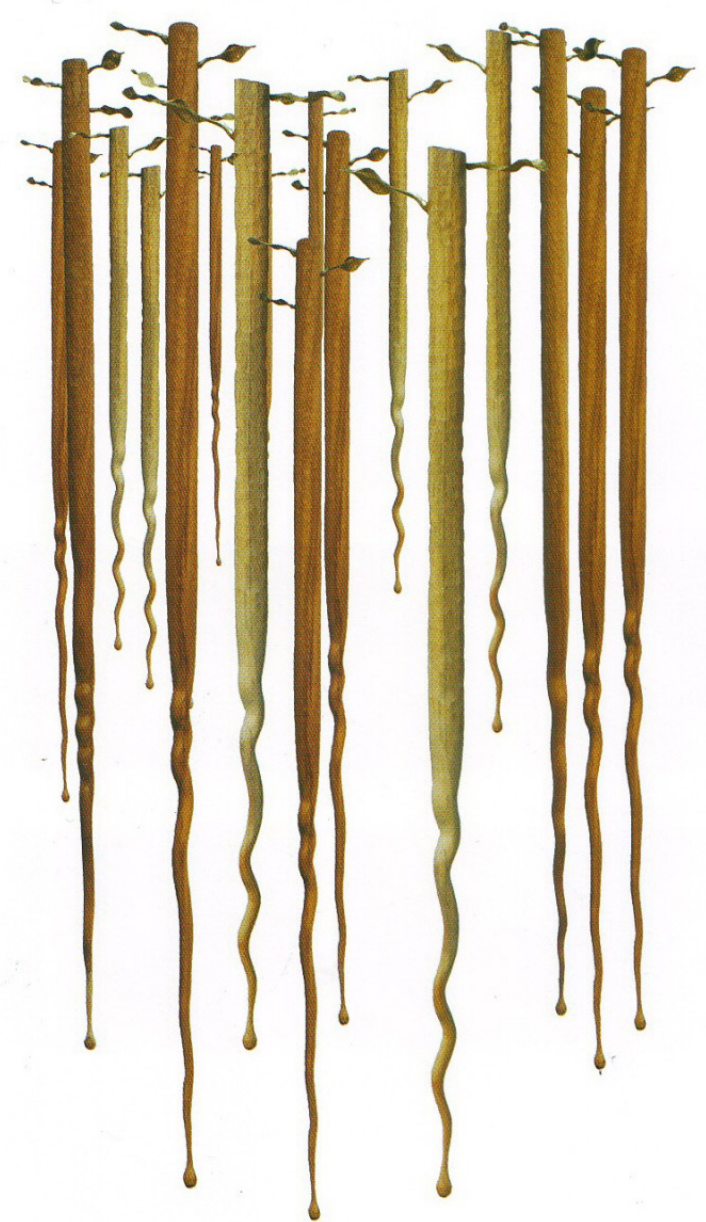

Gambar 8. Cerita Tentang Alamku Kini, 2010, variable dimension (50 pieces), kayu jati, dan kuningan. (Rep. katalog pameran seni rupa "Sensuous Objects", 2010).

keadaan alam saat ini, yang kurang perhatiannya umat manusia terhadap alam, menyebabkan terjadinya kerusakan alam termasuk hutan yang banyak ditebangi untuk lahan perkebunan dan perumahan. Keadaan inilah yang membuat Upadana terkadang tertekan merasa prihatin terhadap alam. Pohon adalah pilar kehidupan yang dianugerahkan alam yang melindungi manusia dari terik panas matahari, tempat burung berteduh dan berkicau serta penyuplai oksigen kehidupan, kini hanya tinggal beton yang menjulang tinggi dengan kayu-kayu yang berserakan tanpa arti. Pohon yang mencair ini dihasratkan sebagai ungkapan kepedihan dari alam, pohon ini mempunyai kesan yang menetes, ringkih, dan tidak berdaya.

Upadana memang selalu memiliki perhatian yang kuat terhadap keseimbangan manusia dan alam, konsep budaya yang diusungnya, yakni Tri Hita Karana, yang menghasratkan perilaku 
keseimbangan antara manusia, alam, dan Tuhan. Memerilakukan alam seperti kita berinteraksi dengan diri kita sendiri dan kecintaan kita pada Tuhan. Konsep lokal yang membumi dan memang harus selalu dipertahankan dan diluaskan untuk kelestarian alam.

Secara gagasan, tema, narasi bentuk karya, dan pemilihan material, Upadana telah berhasil menyampaikan gagasannya dengan cara yang lugas mudah dipahami dengan materi yang alami dan ada di sekitar kehidupan manusia. Tinggal sekarang, bagaimana konsep karya mampu dipahami dan berinteraksi dengan lugas dan informatif kepada penonton sehingga hubungan timbak balik seperti konsep istilah instalasi di atas dapat tercapai.

\section{Karya Instalasi Made Wiguna Valasara}

Deretan AC (Air Conditioner) terpasang dengan ritme teratur berulang di dinding ruang pameran. Sejumlah 15 (lima belas) AC berwarna putih dihiasi corak lidah api dari logam alumunium sejumlah 20 (dua puluh) buah menempel pada elemen material AC. Objek AC dibuat berbanding satu dengan ukuran aslinya deangan material fibre glass atau resin melalui teknik cor, lalu dirakit dengan menempelkan lidah api alumunium. Karya ini mengolah bentuk repitisi baik pada $\mathrm{AC}$ maupun lidah api, namun pada lidah walau repitisi bentuk namun variatif pada ukuran objek (lihat gambar 9).

Lewat karya "Membakar Ruang", Valasara ingin bercerita mengenai sebuah gambaran perilaku manusia dan keadaan alam saat ini, yaitu penggunaan pendingin ruangan yang sangat berlebihan apalagi AC tersebut masih menggunakan material Freon sebagai elemen pendinginnya, sangat merusak ekologi ozon di atmosfer. Walau sudah sangat disadari dampak buruknya terhadap alam, itulah keegoisan manusia yang kurang peduli, yang dipikirkan adalah sematamata mencari kenyamanan sendiri, kenyamanan yang berdampak buruk terhadap kondisi kestabilan ruang lingkup yang sangat luas, yaitu jagat raya dan seluruh kehidupannya.

Ide judul "Membakar ruang" menjadi sangat paradoks, namun berhasil menghadirkan nilai pertentangan visual, jika harusnya yang bersifat membakar itu adalah api, namun di sini AC

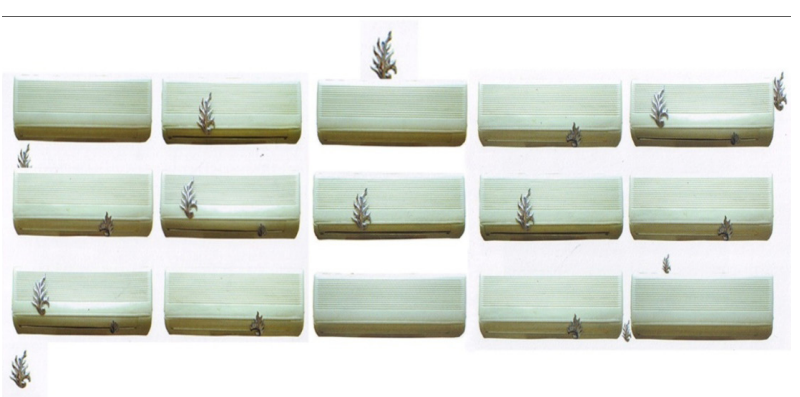

Gambar 9. Membakar Ruang, 2010, 30 × 80 x 23 cm (20 pieces), polyester resin, alumunium, dan stiker. (Rep. katalog pameran seni rupa "Sensuous Objects", 2010).

dengan piranti freonnya yang diibaratkan bersifat membakar melalui pemanasan global bumi sebagai simbol ruang mahaluas. Eksplorasi gagasan dan medium ini menjadi sebuah trik yang bagus untuk mengingatkan penonton pameran untuk refleksi ke dalam, refleksi ke lingkungan luar atas fenomena yang sangat up to date, yang selalu menggejala di sekitar perikehidupan manusia.

Secara umum karya instalasi yang dihadirkan Upadana dan Valasara dalam ruang pameran Sensuous Objects mengangkat isu alam sebagai tema besar atas tragedi kemanusiaan, tragedi penderitaan jagat raya. Bagaimanapun juga karya instalasi membutuhkan peran aktif penikmat karya dan juga harus selalu bisa menarik perhatian dan partisipasi aktif sehingga motivasi gagasan karya dapat tercapai. Seperti yang diungkapkan Julie H. Reiss "Patung-patung (pada seni instalasi) dengan karakter terbaru mengalami estetika kontemporer... karya-karya tersebut membutuhkan perhatian kita dan partisipasi aktif (Reiss, 1999:53).”

Dari pembahasan setiap karya, baik dari elemen visual, konsep karya, tema, gaya, maupun eksplorasi medium tampaknya para perupa tidak hanya memiliki minat yang besar terhadap penyajian visual yang menarik dan bernilai estetis, namun juga mengkaji nilai kontekstualitasnya terhadap isu-isu terkini yang beredar di sekelilingnya. Tema budaya, isu lingkungan, pengaruh teknologi hingga perkembangan pariwisata menjadi inspirasi yang tiada kunjung usai dipresentasikan. Para perupa sudah memiliki kemampuan verbal penciptaan yang kuat, dengan karakter pribadi material yang juga dinamis. Bentuk formal karya bisa timbul oleh eksplorasi medium, namun bisa juga terinspirasi oleh tema yang sudah tergagas sebelumnya. 
Identitas kebentukan karya tidak terlalu penting, yang terpenting karya mampu menampilkan visual ide yang sejalan menegoisasikan konsep-konsep penciptaan, baik konsep medium maupun konsep kontekstual.

\section{Simpulan}

Pembacaan estetika atas karya yang dihasilkan Upadana dan Valasara yang menjadi subjek penelitian ini, menggiring posisi kesenian mereka ke dalam ranah estetika seni rupa kontemporer yang ditandai dengan proses penciptaan kekaryaan yang tidak terbatasi media konvensional, secara konsepsi karya adanya konsep tradisi lokal yang terkandung melalui penciptaan karya.

Seni rupa Bali akan selalu mengalami perkembangan dan perubahan. Melalui pengkajian estetika dari seni rupa Bali klasik, modern hingga kontemporer terlihat perubahan atau transformasi estetika yang berkembang dari waktu ke waktu. Transformasi estetikanya terjadi baik dari segi material bahan, teknis penciptaan, bentuk, tema, hingga konsepsinya. Perubahan ini pasti akan selalu terjadi dan estetikanya akan mengalir seiring semangat zaman dan generasi penerusnya. Dengan begitu, tradisi dan nilainilai lokal itu menjadi aktual tetap berlandaskan pada spirit, ruh lokalitas melalui penciptaan karya dengan metode kontemporer, segar, dan mudah diapresiasi publik.

Seni rupa kontemporer Bali tidak terlepas oleh kuatnya daya tarik dan eksplorasi nilainilai lokalitas baik perupa yang berproses kreatif di Bali maupun luar Bali (YogyakartaJawa). Selain itu, pengaruh sosial-budaya mereka berproses kreatif sangat memengaruhi hasil akhir pemikiran dan penciptaan karya. Pengenalan mereka terhadap sejarah seni rupa Indonesia, persentuhan dengan karya seni yang berkembang di Yogyakarta, pergaulan akademik di ISI Yogyakarta hingga interaksi mental di Sanggar Dewata Indonesia memberikan efek penciptaan yang beragam, unik, dan khas sesuai pribadi masing-masing.

Perupa kontemporer yang menjadi subjek dalam penelitian ini adalah I Wayan Upadana dan I Made Wiguna Valasara mempunyai metodologi penciptaan dengan pendekatan material dan ide/ gagasan yang sifatnya khas dan individual. Melalui kajian kritik seni dengan pertimbangan penilaian kritik, yakni formalisme, ekspresivisme, dan instrumentalisme maka akan dijumpai kualitas formal kebentukan, kualitas ekspresif melalui gagasannya hingga motivasi, alasan kontekstual, dan sikap seniman dalam menanggapi budaya dan lingkungannya.

Masing-masing perupa mempunyai strategi kreatif dalam mentransformasikan sesuatu menjadi sesuatu yang lain. Upadana telah mengembangkan cara pandang yang berbeda dalam mengungkapkan tradisi mematung Bali, tetapi tetap menggandeng isu lokalitas dengan material modern seperti logam, resin, dan barang bekas konsumsi harian dengan kebentukan karya yang ringan, minimalis, berwarna cerah ( $p o p)$, dan objek (aktor) yang terparodikan. Valasara dengan cerdas mentransformasikan ketegangan sosial, mitos-mitos lokal menjadi parodi melalui pendekatan transmedia seperti gabungan media lukisan, patung, instalasi hingga konsep bentuk barang kerajinan; dakron, spon, logam, kardus hingga plastik bekas konsumsi.

Material bahan menjadi salah satu daya tarik lain dalam estetika seni kontemporer. Pendekatan eksplorasi medium dari Upadana dan Valasara untuk bersinergi dengan unsur tradisi-modernkontemporer, yakni transmedia melalui berbagai macam olah media modern seperti kayu, batu, polyester resin, alumunium, baja, barang temuan konsumsi harian hingga barang industri. Medium penyampaian pun beragam, tidak melulu secara konservatif, tetapi menggabungkan antara konsep estetika seni lukis, seni patung, performance art, hingga seni instalasi menjadi satu komponen karya.

\section{Ucapan Terima Kasih}

Ucapan terima kasih disampaikan kepada Perupa Upadana dan Valasara atas karya seni yang indah dan memukau, Lembaga Penelitian ISI Yogyakarta yang telah mendanai penelitian ini, 
SDI Yogyakarta yang telah meminjami katalog dan wawancaranya.

\section{Kepustakaan}

Ardi, Sun. 2006. "Sejarah Seni Rupa dan Proses Pembelajaran Seni Rupa”, dalam M. Agus Burhan (ed) Jaringan Makna: Tradisi hingga Kontemporer Kenangan Purna Bakti untuk Prof. Soedarso Sp., M.A. Yogyakarta: BP ISI Yogyakarta.

Burhan, M. Agus. 2009. "Perkembangan Fakultas Seni rupa ISI Yogyakarta dan Tokoh-tokoh Senimannya" dalam Katalog Pameran Besar Seni Visual Indonesia Exposign 25 tahun ISI Yogyakarta, JEC Yogyakarta, 25 November-30 Desember 2009.

Feldman, Edward Burke.1967. Art as Image and Idea. New Jersey: Prentice-Hall Inc.

Hasan, Asikin ed. 2001. Dua Seni Rupa Sepilihan Tulisan Sanento Yuliman. Jakarta: Yayasan Kalam.

Marianto, M. Dwi. 2001. "Gelagat Yogyakarta Menjelang Millenium Ketiga”, dalam Outlet: Yogya dalam Peta Seni Rupa Kontemporer Indonesia. Yoyakarta: Yayasan Seni Cemeti.
Parta, I Wayan Seriyoga. 2010. "Dari Eksplorasi Medium Kepersoalan Konteks”. Katalog. Pameran Sensous Objects di Bentara Budaya Yogyakarya, 2-9 Juni 2010.

Ragans, Rosalind. 2005. Arttalk. USA: McGrawHill.

Rosidi, Rain. 2010. "Sensuous Objects" dalam Katalog Pameran Seni Rupa Sensuous Objects, Bentara Budaya Yogyakarta, 02-09 Juni 2010.

Reiss, Julie H.1999. From Margin to Center: the Space ofinstallation Art. New York: Massachusetts Institute of Technology.

Sahman, Humar. 1993. Mengenal Dunia Seni Rupa: Tentang Seni, Karya Seni, Aktivitas Kreatif, Apresiasi, Kritik dan Estetika. Semarang: IKIP Semarang Press.

Soedarsono, R.M. 1999. "Seni sebagai Komoditas Seni", dalam R.M Soedarsono, Seni Pertunjukkan dan Pariwisata: Rangkuman Esai tentang Seni Pertunjukan Indonesia dan Pariwisata. Yogyakarta: ISI Yogyakarta.

Sumardjo, Jakob. 2009. Asal Usul Seni Rupa Indonesia. Jawa Barat: Penerbit Kelir.

Yuliman, Sanento. 2001. "Dinamika Bali di Batuan” dalam Asikin Hasan (Ed.). Dua Seni Rupa. Jakarta: Yayasan Utan Kayu. 